\title{
Synthesis of $\mathrm{Na}^{+} / \mathrm{K}^{+}$ATPase by the preimplantation rabbit blastocyst
}

\author{
E. W. Overström*, D. J. Benos† and J. D. Biggers \\ Department of Physiology and Biophysics, Laboratory of Human Reproduction and Reproductive \\ Biology, Harvard Medical School, 45 Shattuck Street, Boston, Massachusetts 02115, USA
}

\begin{abstract}
Summary. The rates of incorporation of $\left[{ }^{35}\right.$ S $]$ methionine into $\mathrm{Na}^{+} / \mathrm{K}^{+}$ATPase, actin ( $\beta$ - and $\gamma$-isoforms), and total protein of the preimplantation rabbit blastocyst were determined between Days 4 and 7 of development. Blastocyst proteins were metabolically radiolabelled with $\left[{ }^{35} \mathrm{~S}\right]$ methionine and subsequently analysed by co-isolation with purified $\mathrm{Na}^{+} / \mathrm{K}^{+}$ATPase using two-dimensional polyacrylamide gel electrophoresis, immunoprecipitation, immunoblotting, fluorography, and liquid scintillation spectroscopy. The rate of $\left[{ }^{35} \mathrm{~S}\right]$ methionine incorporation into acid-soluble total protein increased 24-fold between Days 4 and 6 post coitum (p.c.), then diminished $\sim 79 \%$ on Day 7. In-vitro incorporation of $\left[{ }^{35} \mathrm{~S}\right]$ methionine was linear at each stage of blastocyst development. $\left[{ }^{35} \mathrm{~S}\right]$ methionine incorporation rates were unaffected by low free intracellular methionine concentration $(<0.06 \mathrm{~mm})$ and stage-related differences in blastocoele volume. Analysis of $\beta$ - and $\gamma$-actin synthesis revealed patterns of $\left[{ }^{35}\right.$ S $]$ methionine incorporation rates which were similar to those of total protein. In contrast, synthesis of blastocyst $\mathrm{Na}^{+} / \mathrm{K}^{+}$ATPase was characterized by a 90 -fold increase $(P<0.001)$ in the rate of $\left[{ }^{35} \mathrm{~S}\right]$ methionine incorporation between Days 4 and 6 p.c. The results demonstrate that $\mathrm{Na}^{+} / \mathrm{K}^{+}$ATPase is actively synthesized at a high and increasing rate during preimplantation development in the rabbit at a period which is characterized by rapid fluid accumulation by the blastocyst.
\end{abstract}

Keywords: rabbit; blastocyst; protein synthesis; $\mathrm{Na}^{+} / \mathrm{K}^{+}$ATPase

\section{Introduction}

During mammalian embryogenesis, many distinct morphological and physiological changes occur. Among these is the formation of tight junctions between adjacent blastomeres (Ducibella et al., 1975), which in the rabbit occurs at the 8- to 16-cell stage (Hastings \& Enders, 1975). This process, termed compaction (Ducibella \& Anderson, 1975; Ziomek \& Johnson, 1980), establishes morphological and functional polarization of the embryonic cells and spatially segregates these cells into two subsets, the inner cell mass (ICM) and the trophectoderm. The inner cell mass subsequently differentiates to form the embryo proper in an environment isolated from direct maternal influence. The outer embryonic cells differentiate to form a functional unilaminar epithelium, the trophectoderm. As such, the trophectoderm acts as a selective barrier to solute exchange, thereby regulating the composition of extracellular fluid which bathes the developing inner cell mass (Biggers et al., 1977). Cavitation occurs soon after tight junction formation and is characterized by the accumulation of variable amounts of blastocoelic fluid within the embryo before attachment to the uterine

\footnotetext{
*Present address and reprint requests: Department of Anatomy and Cellular Biology, Tufts University Schools of Veterinary Medicine, Medicine and Dental Medicine, 200 Westboro Road, North Grafton, Massachusetts 01536, USA.

$\dagger$ Department of Physiology and Biophysics, University of Alabama at Birmingham, Birmingham, Alabama 35294, USA.
} 
epithelium (Burgoyne \& Ducibella, 1977). Previous studies in the rabbit have reported that blastocoelic fluid volume increases $\sim 1000$-fold $(70 \mathrm{nl}$ to $80 \mu \mathrm{l}$ ) between Days 4 and 7 of preimplantation development (Daniel, 1964; Biggers et al., 1977), a period of changing protein synthesis activity (Van Blerkom \& Manes, 1974). Mechanisms of active transepithelial solute transport have been reported to mediate this process of blastocoele expansion (see Benos \& Biggers, 1981; Benos et al., 1985, for reviews). Specifically, there is increasing evidence that the ubiquitous membrane-bound enzyme $\mathrm{Na}^{+} / \mathrm{K}^{+}$ATPase (EC 3.6.1.3) mediates transtrophectodermal fluid transport in the preimplantation mammalian blastocyst (Biggers et al., 1978).

In an effort to understand more fully the functional role of $\mathrm{Na}^{+} / \mathrm{K}^{+}$ATPase in differentiation and expansion of the rabbit blastocyst, experiments of the present study were designed to identify blastocyst $\mathrm{Na}^{+} / \mathrm{K}^{+}$ATPase by using procedures of metabolic radiolabelling and two-dimensional polyacrylamide gel electrophoresis (2D-PAGE); and to determine the rate of synthesis of the active $\mathrm{Na}^{+}$transport enzyme between Days 4 and 7 of preimplantation development. Because rates of uptake and incorporation of radiolabelled amino acids by developing embryos can be significantly affected by endogenous amino acid stores and labelling conditions (Regier \& Kafatos, 1971; Epstein \& Smith, 1973; Schultz et al., 1979), we measured the free intracellular methionine pool size in rabbit blastocysts at 4-7 days post coitum and characterized optimum conditions for $\left[{ }^{35}\right.$ S]methionine radiolabelling. The rate of $\mathrm{Na}^{+} / \mathrm{K}^{+}$ATPase synthesis is compared relative to the $\left[{ }^{35} \mathrm{~S}\right]$ methionine incorporation rates determined for total blastocyst protein and $\beta$ - and $\gamma$-actin, two actively synthesized cytoskeletal proteins.

\section{Materials and Methods}

Collection and labelling of blastocysts. Sexually mature New Zealand White rabbits (Meadowbrook Farms, Amherst, MA, USA) were individually caged in a controlled environment $\left(14 \mathrm{~h}\right.$ light:10 h dark, lights on at $\left.07: 00 \mathrm{~h}, 23^{\circ} \mathrm{C}\right)$. Water and commercial rabbit foot were available ad libitum. Animals were twice naturally mated to bucks of proven fertility with the day of mating considered to be Day 0 of pregnancy. On Days 4, 5, 6 and 7 post coitum (p.c.), female rabbits were killed by intravenous injection of pentobarbitone sodium $(1 \mathrm{ml} / \mathrm{kg}$ body wt; Abbott Laboratories, Chicago, IL, USA). The reproductive tract was removed and each uterine horn was flushed with warmed Ham's nutrient medium F10 (F10, GIBCO, Grand Island, NY, USA) containing $20 \mathrm{~mm}$-Hepes buffer adjusted to $\mathrm{pH} 7 \cdot 4$. Recovered blastocysts were immediately transferred to fresh $\mathrm{F} 10$ medium and incubated briefly ( $<15 \mathrm{~min}, 5 \% \mathrm{CO}_{2}$ in humidified air, $37^{\circ} \mathrm{C}$ ) before radiolabelling. Because of their fragility, 7-day p.c. blastocysts were dissected from the uterine horns (Benos, 1981a). Blastocysts were incubated in 1-2 $\mathrm{ml}$ labelling medium for $3 \mathrm{~h}\left(5 \% \mathrm{CO}_{2}\right.$ in humidified air, $37^{\circ} \mathrm{C}$ ). The labelling medium consisted of $\mathrm{F} 10$ containing $200 \mu \mathrm{Ci}\left[{ }^{35} \mathrm{~S}\right]$ methionine $/ \mathrm{ml}$ (sp. act. $>1200 \mathrm{Ci} / \mathrm{mmol}$ : Amersham/Searle, Arlington Heights, IL, USA). To increase the incorporation of label, the unlabelled methionine concentration of the labelling medium was reduced to $0.1 \mu \mathrm{M}$. After labelling, blastocysts were washed in ice-cold F10 medium containing 1 mM-phenylmethylsulphonyl fluoride (PMSF), transferred to a second cold wash and the zonae pellucidae were removed using glass needles under $\times 20$ magnification (Wild M5A stereomicroscope). Blastocysts were gently dissected open to expel blastocoelic fluid, and the tissues were twice washed in cold medium F10 + PMSF. Tissues of 6-20 blastocysts were dissolved in $50 \mu \mathrm{l}$ lysis buffer (O'Farrell, 1975), stored at $-70^{\circ} \mathrm{C}$ and the polypeptides subsequently analysed by 2D-PAGE. Five replicate experiments were carried out for each developmental stage blastocyst (Days 4 to 7 p.c.).

Free intracellular methionine analysis. The procedure of Schultz et al. (1979) was used to quantify the free methionine pool size of 4-, 5-, 6- and 7-day p.c. rabbit blastocyst tissues by reaction with $\left[{ }^{3} \mathrm{H}\right]$ dinitrofluorobenzene with the following modification; blastocysts were cultured in $1 \mathrm{ml} \mathrm{KRBG}$ containing $200 \mu \mathrm{Ci}\left[{ }^{35}\right.$ S $]$ methionine and $20 \mu \mathrm{M}$ unlabelled methionine $\left(5 \% \mathrm{CO}_{2}\right.$ in air, $37^{\circ} \mathrm{C}$ ). Blastocysts were pooled per sample ( 18 for Day 4 to 4 for Day 7 ) and 4-6 samples were analysed for each day of development (Days 4-7 p.c.). [ $\left.{ }^{3} \mathrm{H}\right]$ Dinitrofluorobenzene (sp. act. $>20 \mathrm{Ci} / \mathrm{mmol}$ ) was purchased from New England Nuclear (NEN, Boston, MA, USA). DNP-methionine and polyamide plates were obtained from Sigma Chemical Company (St Louis, MO, USA) and Accurate Chemical and Scientific Co. (Westbury, NY, USA) respectively.

Kinetics of in-vitro ${ }^{35} \mathrm{~S} /$ methionine incorporation. Blastocysts were collected and cultured in labelling medium containing $200 \mu \mathrm{Ci}\left[{ }^{3} 5\right]$ methionine/ml as previously described. After labelling for $0 \cdot 5,1,2$ and $3 \mathrm{~h}$, groups of 3-5 blastocysts were removed and individually washed in $5 \mathrm{ml}$ cold medium F10 + PMSF. Blastocoelic fluid samples $(2-10 \mu l)$ were obtained by micropuncture from 6 - and 7-day embryos for subsequent determination of ${ }^{35} \mathrm{~S}$ radioactivity. Zona-free tissue of individual blastocysts was washed in cold F10-PMSF, solubilized in $25 \mu \mathrm{l}$ SDS sample buffer $(0.0625 \mathrm{M}$-Tris, $10 \%(\mathrm{w} / \mathrm{v})$ glycerol, $5 \%(\mathrm{v} / \mathrm{v}) 2$-mercaptoethanol, $2.6 \% \mathrm{SDS}, \mathrm{pH} 6 \cdot 8)$ and subjected to 3 freezethaw cycles. The specific radioactivity present in acid-precipitable and acid-soluble tissue lysate was determined by the 
procedure of Van Blerkom (1978) with modification. Briefly, duplicate $5 \mu$ l samples of tissue lysate were added to $1.5 \mathrm{ml}$ microcentrifuge tubes containing $0.5 \mathrm{ml}$ distilled water and $100 \mu \mathrm{l} 0.2 \%$ bovine serum albumin (BSA). After the addition of $0.5 \mathrm{ml}$ ice-cold $30 \%$ trichloroacetic acid (TCA), proteins were precipitated for $1 \mathrm{~h}$ at $4^{\circ} \mathrm{C}$. Protein precipitates were centrifuged $(12000 \mathrm{~g}$, for $10 \mathrm{~min}$ and twice suspended, washed with ice-cold $5 \%$ TCA and recentrifuged. The TCA-precipitable $\left[{ }^{35}\right.$ S]methionine activity was determined by liquid scintillation spectroscopy (Beckman 6800 ). Acid-soluble radioactivity was determined by counting triplicate $10 \mu \mathrm{l}$ samples of supernatant from the initial precipitate centrifugation.

Polyacrylamide gel electrophoresis. Labelled blastocyst samples were thawed and frozen 3 times, and the acidprecipitable ${ }^{35} \mathrm{~S}$ radioactivity (d.p.m.) was determined as described. After solubilizing blastocyst tissue in lysis buffer, $>94 \%$ of the total blastocyst radioactivity was present in the supernatant after centrifugation at $100000 \mathrm{~g}$ for $45 \mathrm{~min}$. Solubilized blastocyst proteins were separated by high resolution two-dimensional PAGE (O'Farrell, 1975) as modified for mammalian embryos by Van Blerkom (1978). Synthesized blastocyst $\mathrm{Na}^{+} / \mathrm{K}^{+}$ATPase was identified by coelectrophoresis of $\left[{ }^{35}\right.$ S]methionine-labelled blastocyst proteins with purified $\mathrm{Na}^{+} / \mathrm{K}^{+}$ATPase $\alpha$-subunit. Purified $\mathrm{Na}^{+} / \mathrm{K}^{+}$ATPase $(5 \mu \mathrm{g})$ was added to each blastocyst sample $\left(3 \times 10^{6}\right.$ d.p.m. of acid-precipitable ${ }^{35} \mathrm{~S}$ activity) before isoelectric focussing (IEF, 5\% polyacrylamide, 9.5 M-urea, 3.5\% NP-40, 2\% ampholines 50:50, pH 3-10:pH 4-6). Labelled blastocyst proteins and purified $\mathrm{Na}^{+} / \mathrm{K}^{+}$ATPase were co-separated by IEF ( $\left.6400 \mathrm{Vh}\right)$ and subsequently resolved according to their molecular weights on SDS polyacrylamide slab gels (7-15\% exponential gradient). Gels were fixed $(50 \% \mathrm{MeOH})$ and silver stained (Morrissey, 1981) to visualize $\mathrm{Na}^{+} / \mathrm{K}^{+}$ATPase and other blastocyst proteins. Gels were dried under vacuum, exposed to unflashed XAR-5 film (Kodak) for $2-4$ days at $-70^{\circ} \mathrm{C}$, and the resulting autoradiographs were developed by autoprocessing (Kodak X-OMAT M-60). Na ${ }^{+} / \mathrm{K}^{+}$ATPase ( $\alpha$-subunit) and $\beta$ - and $\gamma$-actin spots were excised from stained gels and solubilized overnight in glass minivials (Rochester Scientific Co., Rochester, NY, USA) containing $100 \mu$ l Protosol (NEN) at $60^{\circ} \mathrm{C}$. After cooling, $3 \mathrm{ml}$ Bioflour (NEN) were added to each vial and the sample radioactivity (expressed as d.p.m.) was determined using a Beckman LS-6800 liquid scintillation counter programmed for quench correction of ${ }^{35} \mathrm{~S}$ in silver-stained polyacrylamide gel samples.

Purified $\mathrm{Na}^{+} / \mathrm{K}^{+}$ATPase. The purified catalytic, $\alpha$-subunit $\left(M_{\mathrm{r}} \sim 100000\right)$ of $\mathrm{Na}^{+} / \mathrm{K}^{+}$ATPase, prepared from shark rectal gland, was kindly provided by Dr J. C. Skou (Skou \& Esmann, 1979). Rabbit kidney $\mathrm{Na}^{+} / \mathrm{K}^{+} \mathrm{ATPase}$ ( $\alpha$-subunit) was isolated and purified as described by Jorgenssen (1974). Both purified enzyme preparations were stored in $30 \mathrm{~mm}$-imidazole, $1 \mathrm{~mm}$-EDTA $\left(\mathrm{pH} \mathrm{7-4)}\right.$ and $25 \%(\mathrm{v} / \mathrm{v})$ glycerol at $-70^{\circ} \mathrm{C}$. The purity of the $\mathrm{Na}^{+} / \mathrm{K}^{+}$ ATPase preparations was determined by one-dimensional SDS-PAGE as described by Van Blerkom (1978).

Immunoprecipitation of blastocyst $\mathrm{Na}^{+} / \mathrm{K}^{+}$ATPase. Day- 6 blastocysts were radiolabelled as described and trophectodermal $\mathrm{Na}^{+} / \mathrm{K}^{+}$ATPase was identified by immunoprecipitation (Tarone et al., 1984). After labelling, the isolated tissues of 4-8 blastocysts were placed in $1.5 \mathrm{ml}$ microfuge tubes containing $0.75 \mathrm{ml}$ Tris-buffered saline ( $150 \mathrm{~mm}-\mathrm{NaCl}, 20 \mathrm{~mm}$-Tris-HCl, $5 \mathrm{~mm}$-EDTA) containing $1 \mathrm{mM}-\mathrm{PMSF}, 0 \cdot 5 \%$ Triton X-100, $0 \cdot 1 \%$ SDS and $0 \cdot 5 \%$ sodium deoxycholate (TDS buffer) for $30 \mathrm{~min}$ at $4^{\circ} \mathrm{C}$. Samples were sonicated $\left(3 \times 10 \mathrm{sec}, 4^{\circ} \mathrm{C}\right)$ and lysates were prepared by centrifugation $(12000 \mathrm{~g}, 10 \mathrm{~min})$. To $0.5 \mathrm{ml}$ samples of lysate were added $20 \mu \mathrm{l} \mathrm{Na}{ }^{+} / \mathrm{K}^{+} \mathrm{ATPase}$ antiserum. The polyclonal antiserum (rabbit) was raised against the purified $\alpha$-subunit (catalytic subunit, $\left.M_{\mathrm{r}} \sim 100000\right)$ of sheep kidney $\mathrm{Na}^{+} / \mathrm{K}^{+}$ATPase (Ball et al., 1983). After incubation $\left(24 \mathrm{~h}, 4^{\circ} \mathrm{C}\right), 50 \mu \mathrm{l}$ of a $10 \%$ suspension of fxed Staphylococcus aureus cells (IgGsorb) were added and incubated for $30 \mathrm{~min}\left(4^{\circ} \mathrm{C}\right)$. Immunoprecipitates were centrifuged $(10000 \mathrm{~g})$ and washed $(\times 3)$ with ice-cold TDS buffer, solubilized in SDS sample buffer, heated $\left(90^{\circ} \mathrm{C}, 3 \mathrm{~min}\right)$ and analysed by one-dimensional PAGE and autoradiograph. Treatment of labelled blastocyst lysate with non-immune rabbit serum served as a negative control.

Statistical analysis. The uptake of $\left[{ }^{35}\right.$ S]methionine by groups of 4-, 5-, 6- and 7-day rabbit blastocysts was determined 5 times at random. Rates of incorporation into total protein, $\mathrm{Na}^{+} / \mathrm{K}^{+}$ATPase and actin $(\beta$ - and $\gamma$-) were measured on each sample of pooled blastocysts. The observations on each sample therefore formed a vector of correlated observations. A curvilinear regression analysis was performed on each of the sets of data to determine the lowest order polynomial needed to fit the observations. The analysis was done by applying a one-way ANOVA, and partitioning the sum of squares attributed to variation between days by means of orthogonal polynomial coefficients. This method of analysis was chosen, rather than a multiple regression analysis, because (1) the procedure provides independent tests of significance of the linear, quadratic and cubic components in testing for the required degree of curvilinearity (Fisher, 1920; Sokal \& Rohlf, 1981), and (2) it provides a greater computing accuracy (Draper \& Smith, 1981).

\section{Results}

\section{Free intracellular methionine content}

The concentration of free methionine in blastocyst tissue is shown in Table 1. The methionine pool size increased from 0.32 to $27 \cdot 1$ pmol per blastocyst between Days 4 and 7 of development, which reflects an 85 -fold increase. However, when endogenous methionine pool values are 
expressed on the basis of $\mu \mathrm{g}$ DNA or blastocyst cell number the concentration of intracellular methionine was essentially unchanged between Days 4 and 7 of development.

Table 1. Free intracellular methionine content in 4- to 7-day rabbit blastocysts

\begin{tabular}{|c|c|c|c|c|c|c|}
\hline \multirow{2}{*}{$\begin{array}{l}\text { Day } \\
\text { p.c. }\end{array}$} & \multirow{2}{*}{$\begin{array}{c}\text { No. of } \\
\text { blastocysts }\end{array}$} & \multirow{2}{*}{$\begin{array}{l}\text { Methionine pool } \\
\text { (pmol/blastocyst) }\end{array}$} & \multirow{2}{*}{$\begin{array}{c}\text { Blastocyst } \\
\text { cell no. }\end{array}$} & \multirow{2}{*}{$\begin{array}{c}\text { DNA content } \\
\text { (ng/blastocyst) }\end{array}$} & \multicolumn{2}{|c|}{ Methionine content } \\
\hline & & & & & $\mathrm{fmol} / \mathrm{cell}$ & fmol/ng DNA \\
\hline 4 & 58 & $0.32 \pm 0.03$ & $1100^{*}$ & $7 \dagger$ & 0.29 & 0.023 \\
\hline 5 & 49 & $2.98 \pm 0.23$ & $12000 \dagger$ & $78 \div$ & 0.25 & 0.026 \\
\hline 6 & 32 & $12 \cdot 4 \pm 1 \cdot 18$ & $52000 \dagger$ & $338 \div$ & 0.24 & 0.027 \\
\hline 7 & 18 & $27 \cdot 1 \pm 2.35$ & $115000 \dagger$ & 747 & 0.24 & 0.027 \\
\hline
\end{tabular}

Values are mean \pm s.e.m.

*Data from Daniel (1964).

†Estimate based on 6.5 pg DNA per cell.

$\ddagger$ Data from J. E. Butler \& J. D. Biggers (unpublished).

\section{Kinetics of $I^{35}$ S/methionine incorporation into total blastocyst protein}

As shown in Fig. 1, the acid-precipitable ${ }^{35} \mathrm{~S}$ radioactivity incorporated into blastocyst tissue increased linearly during the 3 -h labelling period at each stage of development. Correlation coefficients were $0.978,0.989,0.988$, and 0.979 for $4-, 5-, 6-$ and 7-day blastocysts, respectively. Regression analysis showed that the rates of specific incorporation of $\left[{ }^{35} \mathrm{~S}\right]$ methionine ranged from 39400 to 362000 d.p.m./blastocyst/h.

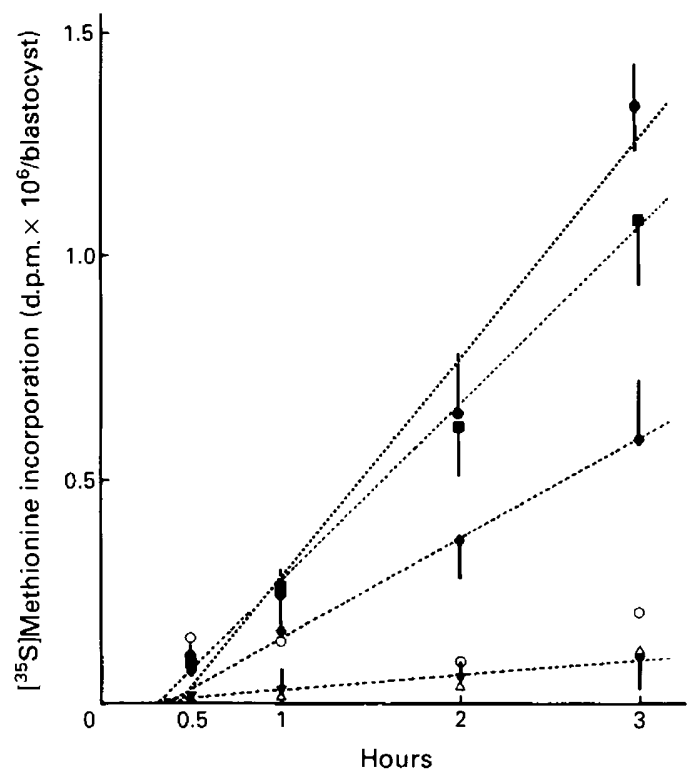

Fig. 1. Time-course of $\left[{ }^{35} \mathrm{~S}\right]$ methionine incorporation by rabbit blastocysts in vitro. The rates of specific incorporation of ${ }^{35} \mathrm{~S}$ radioactivity into $4-(\nabla), 5-(\diamond), 6-(-)$ and $7-(\boldsymbol{\square})$ day blastocysts were determined by TCA precipitation and were linear over the 3-h labelling period. Nonspecific uptake of ${ }^{35} \mathrm{~S}$ radioactivity by tissue $(O$, acid soluble) and zonae pellucidae $(\triangle)$ is also plotted. Values represent the mean \pm s.e.m. of 5 replicate experiments (4-7 embryos per time point). 
Uptake of acid-soluble ${ }^{35} \mathrm{~S}$ radioactivity was low, rapidly saturable $(30 \mathrm{~min})$ and remained constant during the labelling period (Fig. 2, open circles). Similarly, ${ }^{35} \mathrm{~S}$ radioactivity associated with the zonae pellucidae was minimal, with values $<7 \%$ of the total incorporated label (d.p.m.) blastocyst) at each time period. Moreover, $>85 \%$ of zona-associated radioactivity readily eluted from isolated zonae pellucidae when placed in $\mathrm{KRBG}$ overnight $\left(4^{\circ} \mathrm{C}\right)$. Thus, by using the described labelling conditions in all subsequent experiments, rabbit blastocysts were radiolabelled to high ${ }^{35} \mathrm{~S}$ specific activity during a $3-\mathrm{h}$ incubation period.

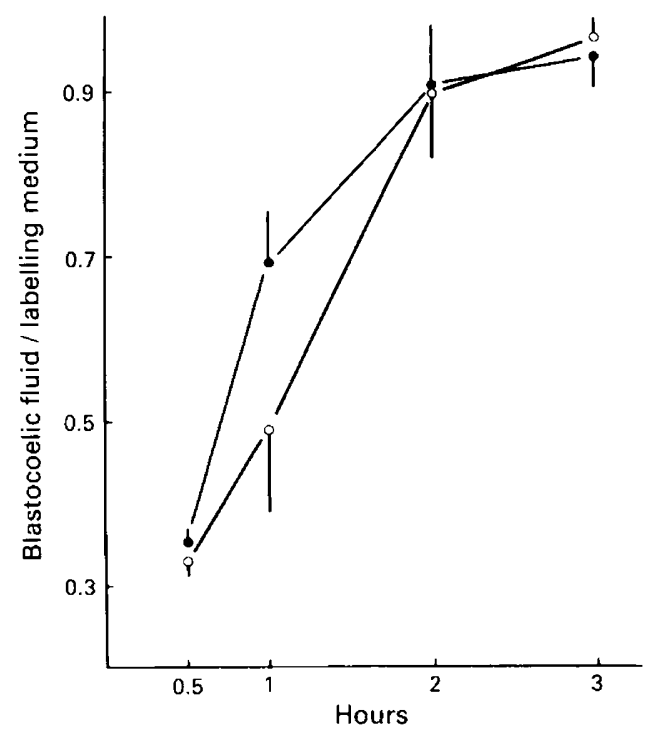

Fig. 2. Time-course of $\left[{ }^{35} \mathrm{~S}\right] \mathrm{methionine}$ equilibration between labelling medium and blastocoelic fluid of 6- $(-)$ and 7-day $(O)$ rabbit blastocysts. Samples of labelling medium and blastocoelic fluid were obtained by micropuncture and sampling of the blastocoele. Values represent the mean \pm s.e.m. of triplicate experiments. For each experiment, 5-8 blastocysts were used per time point.

Because of the large increase in blastocoele volume between Days 4 and 7 p.c., it was possible that blastocoelic fluid may act as a substrate sink and thereby preclude accurate quantitative comparisons of $\left[{ }^{35} \mathrm{~S}\right]$ methionine incorporation rates between blastocysts at different stages. The ${ }^{35} \mathrm{~S}$ specific activity of blastocoelic fluid reached $>90 \%$ of the external medium specific activity within $2 \mathrm{~h}$ (Fig. 3). These results demonstrate that no significant 'sink' effect exists when embryos are labelled for $3 \mathrm{~h}$ under the given conditions.

The arithmetic mean rates of $\left[{ }^{35} \mathrm{~S}\right]$ methionine incorporation into total acid-precipitable blastocyst protein are shown in Table 2 . Because the variances tend to vary directly with the means, all individual observations were transformed to natural logarithms to reduce this dependency. The transformation is appropriate because growth data tend to be distributed lognormally (Sokal \& Rolf, 1981; Hines, 1983). Incorporation of $\left[{ }^{35}\right.$ S]methionine increased 9-fold between Day 4 and Day 5 of development and reached a maximal value just before the 6th day. Thereafter, specific uptake of $\left[{ }^{35} \mathrm{~S}\right]$ methionine by 7 -day embryos decreased $\sim 79 \%$. On a per cell basis, $\left[{ }^{35} \mathrm{~S}\right]$ methionine incorporation rates were similar in 4- and 5-day blastocysts, whereas 6- and 7-day blastocysts showed decreasing rates. Comparisons of free methionine pool size versus rate of $\left[{ }^{35} \mathrm{~S}\right]$ methionine incorporation reveal that the endogenous pool of 4-, 5-, and 6-day blastocysts represented $<1 \%$ of the $\left[{ }^{35} \mathrm{~S}\right]$ methionine incorporated in $1 \mathrm{~h}$, but $\sim 10 \%$ of Day 7 blastocysts (Table 2 ). 


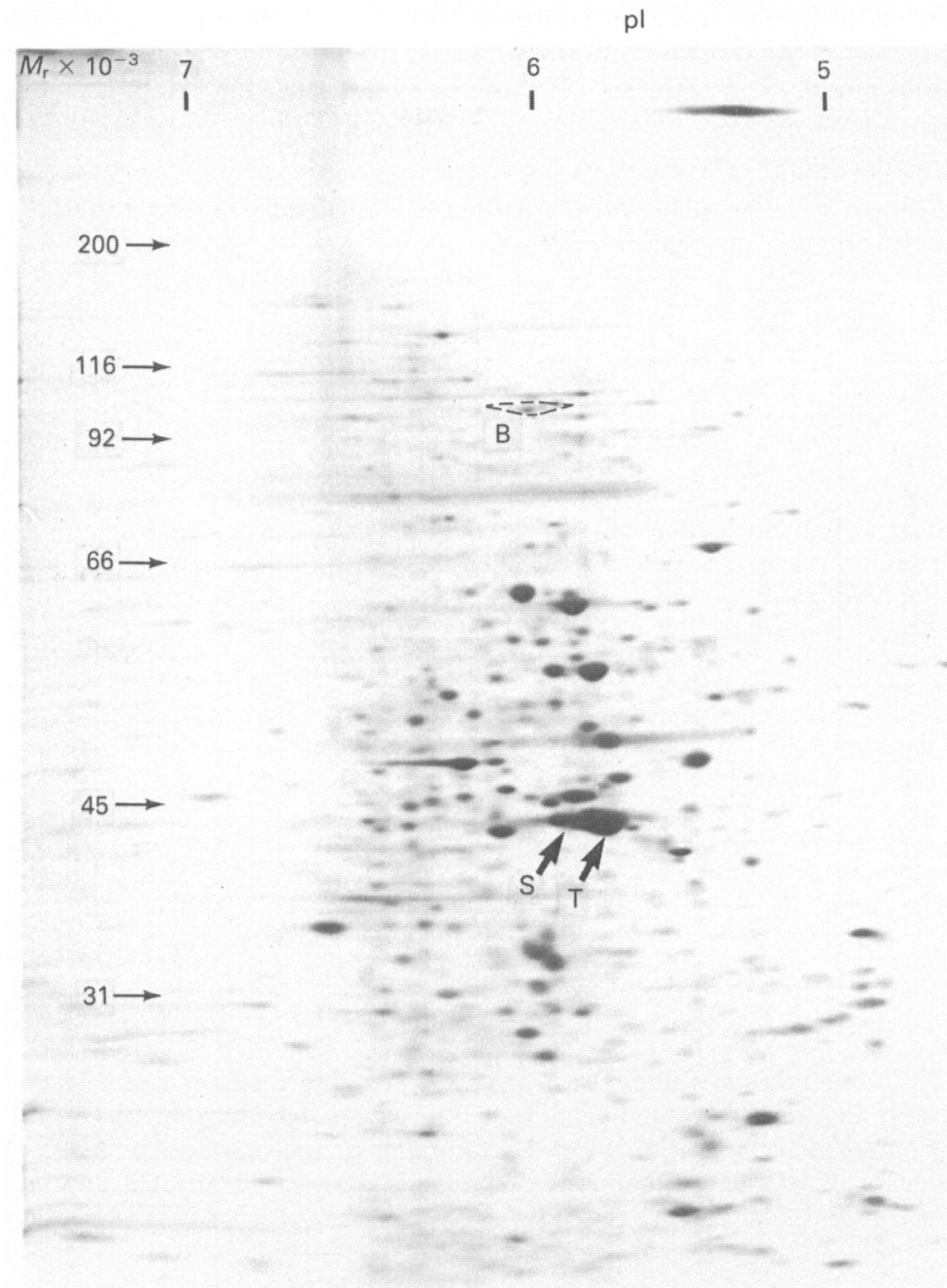

Fig. 3. Fluorograph of dried polyacrylamide slab gel after two-dimensional PAGE separation of $\left[{ }^{35} \mathrm{~S}\right]$ methionine labelled Day- 6 rabbit blastocyst proteins. Approximately $3 \times 10^{6}$ d.p.m. of acid-precipitable ${ }^{35} \mathrm{~S}$ radioactivity and $5 \mu \mathrm{g}$ purified $\mathrm{Na}^{+} / \mathrm{K}^{+}$ATPase were applied to each gel. Blastocyst $\mathrm{Na}^{+} / \mathrm{K}^{+}$ATPase ( $\alpha$-subunit) is protein $\mathrm{B}$ (broken lines indicate region occupied by purified $\mathrm{Na}^{+} / \mathrm{K}^{+}$ATPase), and $\beta$ - and $\gamma$-actin are proteins $\mathrm{T}$ and $\mathrm{S}$, respectively.

Two-dimensional PAGE analysis of $\left[^{35} \mathrm{~S}\right]$ methionine-labelled $\mathrm{Na}^{+} / \mathrm{K}^{+}$ATPase and actin

Figure 3 shows a fluorograph developed from a representative two-dimensional PAGE gel of labelled Day- 6 blastocyst proteins. In general, rabbit blastocyst proteins have molecular weights of 15000 to 325000 and have pI values of 4.5 to 7 . Blastocyst $\mathrm{Na}^{+} / \mathrm{K}^{+}$ATPase, identified by coelectrophoresis with purified enzyme (broken outline), and $\beta$-actin and $\gamma$-actin are proteins $B, T$ and $S$, respectively.

The maximum rate of incorporation of $\left[{ }^{35} S\right]$ methionine and the time it is reached were calculated from the simplest polynomial equation which fitted the data for each protein (Table 3). The $b_{1}$ and $b_{2}$ regression coefficient values demonstrate that $\mathrm{Na}^{+} / \mathrm{K}^{+}$ATPase, $\beta$ - and $\gamma$-actin each 
Table 2. Rates of $\left[{ }^{35}\right.$ S]methionine incorporation by 4-, 5-, 6- and 7-day rabbit blastocysts

\begin{tabular}{|c|c|c|c|}
\hline \multirow{2}{*}{$\begin{array}{l}\text { Day } \\
\text { p.c. }\end{array}$} & \multicolumn{2}{|c|}{$\left[{ }^{35}\right.$ S]Methionine incorporation } & \multirow{2}{*}{$\begin{array}{l}\text { Methionine pool/ } \\
\text { incorporation rate } \\
\text { (h) }\end{array}$} \\
\hline & $\mathrm{pmol} /$ blastocyst $/ \mathrm{h}$ & $\mathrm{fmol} / \mathrm{cell} / \mathrm{h}^{*}$ & \\
\hline 4 & $57 \pm 11$ & 51.8 & 0.0056 \\
\hline 5 & $512 \pm 207$ & $42 \cdot 7$ & 0.0058 \\
\hline 6 & $1377 \pm 462$ & $26 \cdot 5$ & 0.0090 \\
\hline 7 & $262 \pm 67$ & $2 \cdot 3$ & $0 \cdot 1034$ \\
\hline
\end{tabular}

Values are mean \pm s.e.m. for 5 experiments.

*See Table 1 for cell numbers.

Table 3. Estimates of the regression coefficients for the orthogonal polynomials required to summarize the incorporation of $\left[{ }^{35}\right.$ S $]$ methionine into $\mathrm{Na}^{+} / \mathrm{K}^{+}$ATPase and actin by $4-7$ day rabbit blastocysts

\begin{tabular}{|c|c|c|c|c|c|}
\hline \multirow[b]{2}{*}{ Protein } & \multicolumn{3}{|c|}{ Regression coefficients } & \multirow{2}{*}{$\begin{array}{c}\text { Maximum rate } \\
\text { of incorporation } \\
\text { (fmol/blastocyst/h) }\end{array}$} & \multirow{2}{*}{$\begin{array}{c}\text { Time maximum } \\
\text { is reached } \\
\text { (day p.c.) }\end{array}$} \\
\hline & $b_{0}$ & $b_{1}$ & $b_{2}$ & & \\
\hline $\mathrm{Na}^{+} / \mathrm{K}^{+}$ATPase (B) & $19 \cdot 765$ & $5 \cdot 773^{* * *}$ & $-5 \cdot 378 * * *$ & 308 & $6 \cdot 0$ \\
\hline$\gamma$-Actin (S) & $22 \cdot 192$ & $3.618^{* * *}$ & $-4 \cdot 253^{* * *}$ & 334 & $5 \cdot 9$ \\
\hline$\beta$-Actin (T) & $32 \cdot 866$ & $2 \cdot 581^{* *}$ & $-3 \cdot 332^{* * *}$ & 2629 & $5 \cdot 8$ \\
\hline
\end{tabular}

All values of $b_{0}$ were highly significant $(P<0-001)$; all values of $b_{3}$ (the cubic component) were not significant $(P>0.05)$ and are not shown. ${ }^{* *} 0.001<P<0.01 ;{ }^{* * *} P<0.001$.

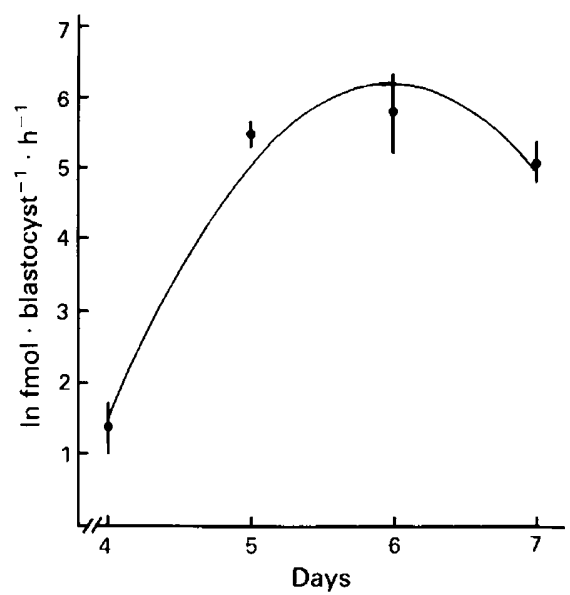

Fig. 4. Rates of incorporation of $\left[{ }^{35} S\right]$ methionine into blastocyst $\mathrm{Na}^{+} / \mathrm{K}^{+}$ATPase (Q). The means \pm s.e.m. are based on 5 replicate observations.

displayed different patterns of $\left[{ }^{35}\right.$ S $]$ methionine incorporation during development, and that the ${ }^{35} \mathrm{~S}$ incorporation rate for each protein increased significantly $(P<0.01$ for actins; $P<0.001$ for $\mathrm{Na}^{+} / \mathrm{K}^{+}$ATPase) between Days 4 and 6 p.c.

The rate of incorporation of $\left[{ }^{35} \mathrm{~S}\right]$ methionine into $\mathrm{Na}^{+} / \mathrm{K}^{+}$ATPase ( $\alpha$-subunit, B) is plotted in Fig. 4. Blastocyst $\mathrm{Na}^{+} / \mathrm{K}^{+}$ATPase showed a $\sim 90$-fold increase $(P<0 \cdot 001)$ in $\left[{ }^{35}\right.$ S]methionine 


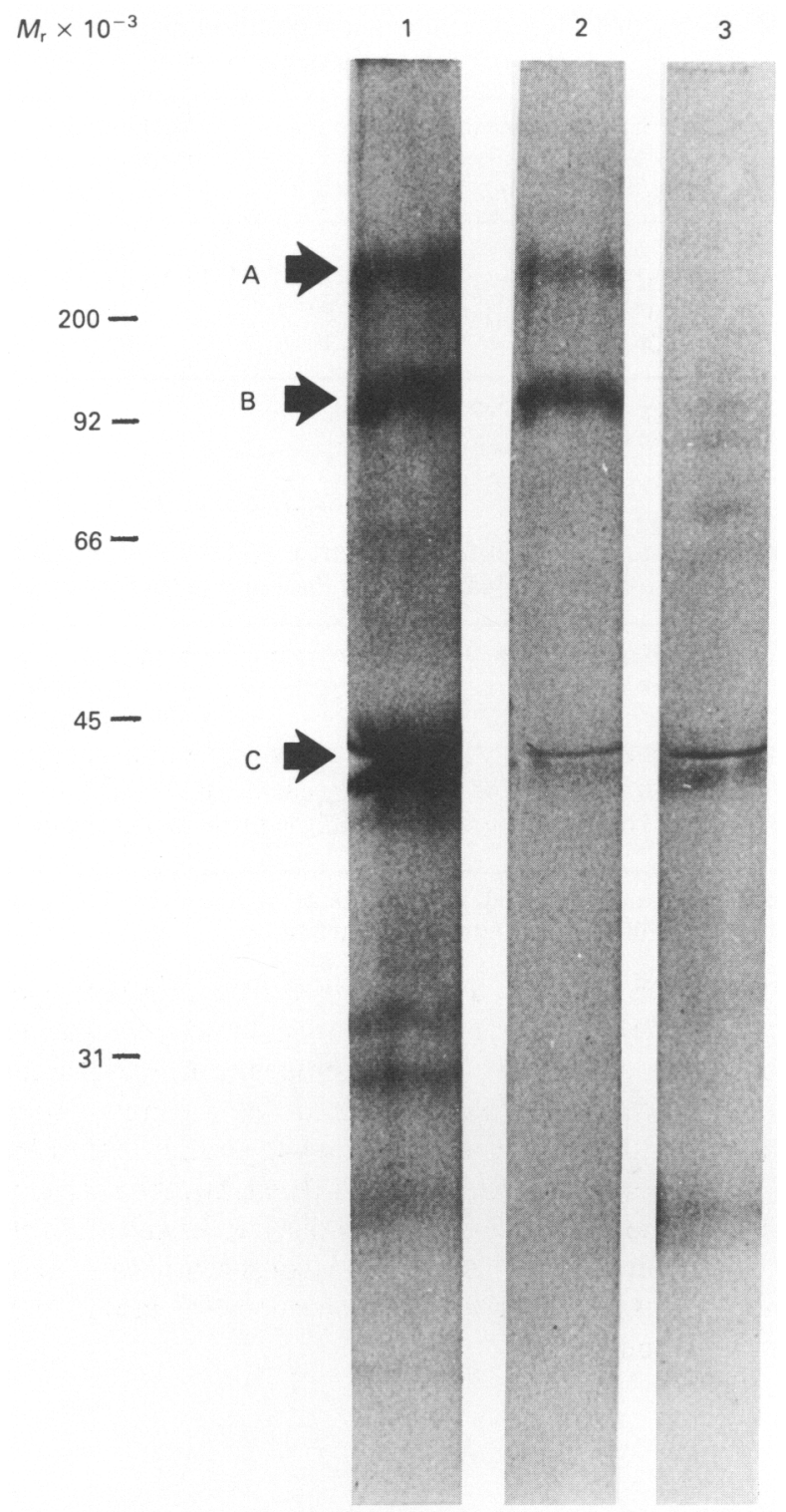

Fig. 5. Fluorograph of immunoprecipitated $\mathrm{Na}^{+} / \mathrm{K}^{+}$ATPase from total Day 6 blastocyst proteins labelled with $\left[{ }^{35}\right.$ S]methionine. Lane 1 shows blastocyst $\mathrm{Na}^{+} / \mathrm{K}^{+}$ATPase, the holenzyme (A) and the $\alpha$-subunit (B) are seen as major bands of $M_{\mathrm{r}} 320000$ and 100000 , respectively. Actin (C) and unidentified background proteins were also precipitated. Lane 2 depicts immunoprecipitated $\mathrm{Na}^{+} / \mathrm{K}^{+}$ATPase after prior precipitation of labelled blastocyst lysate with nonimmune serum, while Lane 3 shows blastocyst proteins which precipitated with non-immune serum alone.

incorporation rate between Days 4 and 6 p.c. $\mathrm{Na}^{+} / \mathrm{K}^{+}$ATPase is among a small subset of blastocyst proteins whose incorporation rates increase most sharply during this period (E. W. Overstrom, D. J. Benos \& J. D. Biggers, unpublished).

The one-dimensional PAGE profile of immunoprecipitated $\mathrm{Na}^{+} / \mathrm{K}^{+}$ATPase from ${ }^{35} \mathrm{~S}$-labelled Day-6 blastocysts is shown in Fig. 5. Anti- $\alpha$ serum precipitated $\mathrm{Na}^{+} / \mathrm{K}^{+}$ATPase, both the 


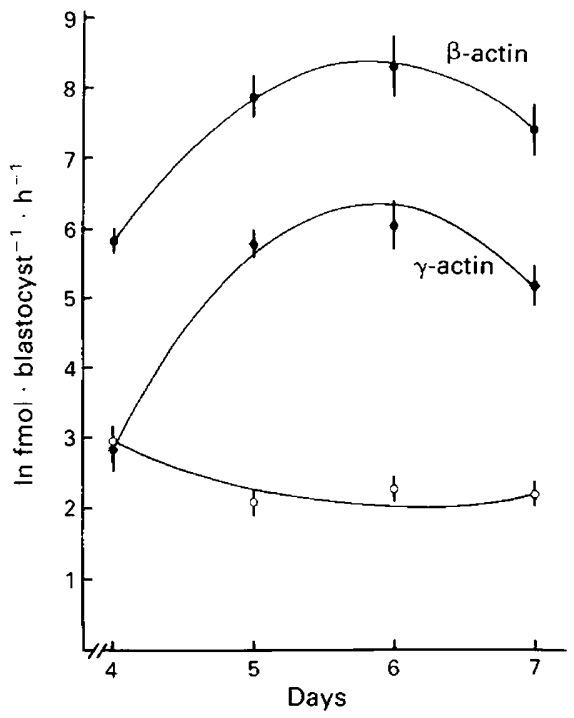

Fig. 6. Comparison of $\left[{ }^{35} \mathrm{~S}\right]$ methionine rates of incorporation into blastocyst $\beta$-actin $(\bullet)$ and $\gamma$-actin $(\bullet)$ with development. Values are means \pm s.e.m. of 5 replicate experiments. Also shown is the regression of the differences $(O)$ between the proteins with respect to developmental age.

holoenzyme $\left(M_{\mathrm{r}} \sim 320000\right)$ and the $\alpha$-subunit $\left(M_{\mathrm{r}} 100000\right)$, and a heterogeneous population of minor proteins. Pretreatment with non-immune serum reduced non-specific precipitation while enhancing immunoprecipitation of $\mathrm{Na}^{+} / \mathrm{K}^{+}$ATPase (holoenzyme and $\alpha$-subunit).

The predominant polypeptide synthesized throughout the preimplantation period was $\beta$-actin (Fig. 6). The cytoskeletal protein displayed a maximum incorporation rate of $2629 \mathrm{fmol} / \mathrm{blastocyst} / \mathrm{h}$ just before Day 6, a 19 -fold increase from Dayt 4 p.c. In contrast, the maximum ${ }^{35} \mathrm{~S}$ incorporation rate for the $\gamma$-actin isoform was $334 \mathrm{fmol} /$ blastocyst $/ \mathrm{h}$ which represents a 27 -fold increase during the same period. Since the regression of the differences in incorporation rates on developmental age is significant, the temporal patterns of $\left[{ }^{35} \mathrm{~S}\right]$ methionine incorporation into $\beta$ - and $\gamma$-actin are different during the preimplantation period.

\section{Discussion}

The results of the present study demonstrate that the rate of incorporation of $\left[{ }^{35} S\right]$ methionine into total blastocyst protein increases 24 -fold then diminishes slightly during preimplantation development in the rabbit. The change in rate is the mean of changes for all individual polypeptides of the blastocyst. This general pattern is reflected in the specific rates of $\left[{ }^{35} \mathrm{~S}\right]$ methionine incorporation into blastocyst $\mathrm{Na}^{+} / \mathrm{K}^{+}$ATPase and actin. Under defined conditions, the $\left[{ }^{35} \mathrm{~S}\right]$ methionine incorporation rates of individual proteins reflect an estimate of their independent rates of synthesis. Several factors, however, must be taken into account. For example, changes in the free endogenous intracellular amino acid pool have been shown to influence directly the rate of incorporation of radiolabelled amino acids by embryos undergoing high rates of differentiation (Regier \& Kafatos, 1971; Epstein \& Smith, 1973; Biggers \& Borland, 1976). We report here that free intracellular methionine concentrations in 4- to 7-day rabbit blastocysts are uniformly low $(<0.06 \mathrm{mM})$. This is in agreement with previous reports that free methionine concentration is very low and comparable in rabbit blastocyst tissue (Petzoldt et al., 1973; Miller \& Schultz, 1987), blastocoelic fluid (Lesinski et al., 1967; Jaszczak 
et al., 1972) and uterine fluid (Jaszczak et al., 1972; Miller \& Schultz, 1987). During radiolabelling, methionine is readily transported into blastomeres by $\mathrm{Na}^{+}$-dependent and $\mathrm{Na}^{+}$-independent mechanisms (Benos, 1981b; Bell et al., 1986) and swamps out the comparatively small endogenous methionine pool. We demonstrate that free methionine rapidly equilibrates between the uterine and blastocoelic compartments which support the work of Miller \& Schultz (1987). Collectively these results suggest that the specific activity of these extracellular compartments is essentially that of the endogenous pool. Although comparisons of $\left[{ }^{35} \mathrm{~S}\right]$ methionine incorporation rates may not reflect accurate comparisons of absolute synthesis rates between different blastocyst proteins because the numbers of methionine residues vary among polypeptides, under the described experimental conditions, the $\left[{ }^{35} \mathrm{~S}\right]$ methionine incorporation rate of an individual blastocyst protein, e.g. $\mathrm{Na}^{+} / \mathrm{K}^{+}$ ATPase, provides an accurate estimate of its changing rate of synthesis between Days 4 and 7 of development.

Changes in protein degradation rates may also influence the rate of $\left[{ }^{35} S\right]$ methionine incorporation into blastocyst proteins. Studies in the mouse (Brinster et al., 1976, 1979) have demonstrated distinct differences in protein degradation rates of cleavage and blastocyst-stage embryos. While it is possible that there is a small population of rabbit blastocyst proteins that turnover at high rates between Days 4 and 7 p.c., it is likely that most of the constitutive proteins have half-lives greater than $3 \mathrm{~h}$ since incorporation into total protein was linear over the 3-h labelling period. Protein degradation rates in preimplantation rabbit blastocysts have not been reported, but in other systems the half-life of $\mathrm{Na}^{+} / \mathrm{K}^{+}$ATPase is greater than $5 \mathrm{~h}$ (Lo \& Edelman, 1976; Cook et al., 1985).

This study presents for the first time direct evidence that blastocyst $\mathrm{Na}^{+} / \mathrm{K}^{+}$ATPase is being synthesized at a rapidly increasing rate between Days 4 and 6 of development in the rabbit. This observation is of particular significance because processes of blastocyst expansion and blastocoele fluid accumulation proceed maximally during this period (Benos \& Biggers, 1981). This finding corroborates several indirect lines of evidence which implicate trophectodermal $\mathrm{Na}^{+} / \mathrm{K}^{+} \mathrm{ATPase}$ in blastocyst formation (DiZio \& Tasca, 1977; Wiley, 1984) and expansion (Borland et al., 1977; Benos \& Biggers, 1981; Benos et al., 1985). As in other transporting epithelia, $\mathrm{Na}^{+} / \mathrm{K}^{+}$ATPase functions to generate an electrochemical gradient across the trophectoderm by actively transporting intracellular $\mathrm{Na}^{+}$out of the cell and into the blastocoele, thereby facilitating the accumulation of blastocoelic fluid (Borland et al., 1976, 1977). Previous reports have established that accumulation of rabbit blastocyst fluid, which increases $>1000$-fold between Days 4 and 7 p.c. (Benos \& Biggers, 1981), is coupled to active solute transport across the trophectoderm (Gamow \& Daniel, 1970; Smith, 1970; Cross, 1973, 1974; Borland et al., 1977). For example, net transtrophectodermal $\mathrm{Na}^{+}$influx increases $\sim 10$-fold during this period (Borland et al., 1976). Ouabain, a specific inhibitor of $\mathrm{Na}^{+} / \mathrm{K}^{+} \mathrm{ATPase}$, has been shown to inhibit both the accumulation of blastocyst fluid (Biggers et al., 1978) and $>50 \%$ of net trans-trophectodermal $\mathrm{Na}^{+}$transport in preimplantation rabbit blastocysts (Benos, $198 \mathrm{lb}$ ). Other studies have shown that the $\mathrm{Na}^{+}$pump is localized within the basal-lateral domains of rabbit and mouse trophectoderm cells (Benos et al., 1985; Watson \& Kidder, 1988). Benos (1981b) has also reported that ouabain binding, a direct measure of $\mathrm{Na}^{+}$'pump sites', increases dramatically in rabbit blastocysts between Days 4 and 6 p.c. This increase in binding parallels the 90 -fold increase in $\mathrm{Na}^{+} / \mathrm{K}^{+}$ATPase synthesis reported here.

The mechanism(s) which controls the rate of synthesis of trophectodermal $\mathrm{Na}^{+} / \mathrm{K}^{+}$ATPase during mammalian blastogenesis is not known. There has accumulated considerable evidence from work in other systems that genetic regulation of synthesis and degradation of the ubiquitous $\mathrm{Na}^{+}$ pump (Boardman et al., 1974; Pollack et al., 1981; Edelman et al., 1985) is modulated by hormonal factors (Jorgenssen, 1972; Geheb et al., 1983; Paccolat et al., 1987; McDonough et al., 1988). Therefore, as the blastocyst undergoes progressively rapid and complex stages of differentiation, and as embryonic development proceeds in an environment of fluctuating hormonal conditions, we postulate that synthesis and functional expression of trophectodermal $\mathrm{Na}^{+} / \mathrm{K}^{+}$ATPase are genetically regulated via mechanisms of hormonal modulation. 
The cause of the reduction in rate of incorporation of $\left[{ }^{35} \mathrm{~S}\right]$ methionine into blastocyst proteins on Day 7 is unclear. Several possibilities exist, including an increase in the rate of trophoblast cell death and slowing of the cell cycle (Daniel, 1964), and a decrease in overall oxidative metabolism (Benos \& Balaban, 1980, 1983). Other physiological studies (Benos, 1981a, b; Benos \& Biggers, 1981; Benos et al., 1985) have identified differences in trophectodermal solute transport properties between 6- and 7-day rabbit blastocysts; functional differences which coincide with decreasing blastocyst uptake and utilization of $\left[{ }^{35}\right.$ S $]$ methionine reported here. These developmentally regulated changes include: (1) the loss of a $\mathrm{Na}^{+}$-dependent methionine transport mechanism; (2) the appearance of an amiloridesensitive component to $\mathrm{Na}^{+}$influx; and (3) the acquisition of a furosemide-sensitive $\mathrm{NaCl}$ co-transport system. In addition, Overstrom et al. (1983) have reported that the composition of iodinated plasma membrane proteins of Day- 6 and Day- 7 blastocysts vary qualitatively with regard to developmental age and their apical or basolateral domains. These observations suggest that dramatic changes in epithelial transport mechanisms reflect the changing developmental expression of trophectodermal membrane constituents, in particular, $\mathrm{Na}^{+} / \mathrm{K}^{+}$ATPase. Such changes may reflect a general 'uncoupling' of oxidative metabolism from ion transport and protein synthesis/ degradation functions to other cellular activities commencing on Day 7 p.c., the day that implantation is initiated.

We thank Ms M. A. Blazonis for excellent technical assistance and Ms C. Kountz, Ms N. Horniak and Ms B. Bannon for preparing the manuscript; Dr C. A. Millette, Dr G. S. Gerton and Dr D. A. O'Brien for helpful discussions and suggestions during the course of this study; and Dr W. Ball, $\mathrm{Jr}$, University of Cincinnati, School of Medicine, Cincinnati, $\mathrm{OH}$, for $\mathrm{Na}^{+} / \mathrm{K}^{+}$ATPase ( $\alpha$-subunit) antiserum.

Animals used in this study were maintained in accordance with the guidelines of the Committee on Animals of the Harvard Medical School and those prepared by the Committee on Care and Use of Laboratory Animals of the Institute of Laboratory Animal Resources, National Research Council (DHEW Publ., NIH 78-23, revised 1978).

This work was supported by NIH Grants HD12353, HD21302, and by funds from the Andrew W. Mellon Foundation. E.W.O. was a Research Fellow supported by NIH T32-HD07130.

\section{References}

Ball, W.J., Collins, J.H., Lane, L.K. \& Schwartz, A. (1983) Studies of the antigenic properties of the catalytic and glycoprotein subunits of $\mathrm{Na}^{+} \mathrm{K}^{+}$ATPase. Archs Biochem. 221, 371-380.

Bell, J.E., Begg, K.E., Sin, Y., Biggers, J.D. \& Benos, D.J. (1986) Neutral amino acid uptake into preimplantation rabbit blastocysts. Am. J. Physiol. 251, C285-C292.

Benos, D.J. (1981a) Ouabain binding to preimplantation rabbit blastocysts. Devl Biol. 83, 69-78.

Benos, D.J. (1981b) Developmental changes in epithelial transport characteristics of preimplantation rabbit blastocysts. J. Physiol., Lond. 316, 191-202.

Benos, D.J. \& Balaban, R.S. (1980) The energy requirements of the developing mammalian blastocyst for active ion transport. Biol. Reprod. 23, 941-947.

Benos, D.J. \& Balaban, R.S. (1983) Energy metabolism of preimplantation mammalian blastocysts. Am. J. Physiol. 234, C40-C45.

Benos, D.J. \& Biggers, J.D. (1981) Blastocyst fluid formation. In Fertilization and Embryonic Development In Vitro, pp. 283-297. Eds L. Mastroianni, Jr and J. D. Biggers. Plenum, New York.
Benos, D.J., Balaban, R.S., Biggers, J.D., Mills, J.W. \& Overstrom, E.W. (1985) Developmental aspects of sodium dependent transport processes in preimplantation rabbit embryos. In Regulation and Development of Membrane Transport Processes, pp. 211-235. Ed. J. S. Graves. John Wiley \& Sons, New York.

Biggers, J.D. \& Borland, R.M. (1976) Physiological aspects of growth and development of the preimplantation mammalian embryo. Ann. Rev. Physiol. 38, 95-119.

Biggers, J.D., Borland, R.M. \& Powers, R.D. (1977) Transport mechanism in the preimplantation mammalian embryo. In The Freezing of Mammalian Embryo (Ciba Fdn Symp. No. 52), 129-153. Eds K. Elliott \& J. Whelan. Elsevier, Amsterdam.

Biggers, J.D., Borland, R.M. \& Lechene, C.P. (1978) Quabain-sensitive fluid accumulation and ion transport by rabbit blastocysts. J. Physiol., Lond. 280, 319-330.

Boardman, L., Huett, M., Lamb, J.F., Newton, J.P. \& Polson, J.M. (1974) Evidence for the genetic control of the sodium pump density in HeLa cells. J. Physiol., Lond. 241, 771-794. 
Borland, R.M., Biggers, J.D. \& Lechene, C.P. (1976) Kinetic aspects of rabbit blastocoele fluid accumulation: an application of electron probe analysis. Devl Biol. 50, 201-211.

Borland, R.M., Biggers, J.D. \& Lechene, C.P. (1977) Fluid transport by rabbit preimplantation blastocysts. J. Reprod. Fert. 51, 131-135.

Brinster, R.L., Wiebold, J.L. \& Brunner, S. (1976) Protein metabolism in preimplanted mouse ova. Devl Biol. 51, 215-224.

Brinster, R.L., Brunner, S., Joseph, X. \& Levy, I.L. (1979) Protein degradation in the mouse blastocyst. J. biol. Chem. 254, 1927-1931.

Burgoyne, P.S. \& Ducibella, T. (1977) Changes in the properties of the developing mouse trophoblast as revealed by aggregation studies. J. Embryol. exp. Morph. 40, 143-157.

Cook, J.S., Karin, N.J., Fishman, J.B., Tate, E.H., Pollock, L.R. \& Hayden, T.L. (1985) Regulation of turnover of $\mathrm{Na}^{+}, \mathrm{K}^{+}$-ATPase in cultured cells. In Regulation and Development of Membrane Transport Processes, pp. 3-19. Ed. J. S. Graves. John Wiley \& Sons, New York.

Cross, M.H. (1973) Active sodium and chloride transport across the rabbit blastocoele wall. Biol. Reprod. 8, $566-575$.

Cross, M.H. (1974) Rabbit blastocoele bicarbonate: accumulation rate. Biol. Reprod. 11, 654-662.

Daniel, J.C., Jr (1964) Early growth of rabbit trophoblast. Am. Natur. 98, 85-97.

DiZio, S.M. \& Tasca, R.J. (1977) Sodium-dependent amino acid transport in preimplantation mouse embryos. III. $\mathrm{Na}^{+}-\mathrm{K}^{+}$-ATPase-linked mechanism in blastocysts. Devl Biol. 59, 198-205.

Draper, N. \& Smith, H. (1981) Applied Regression Analysis, 2nd edn. Wiley, New York.

Ducibella, T. \& Anderson, E. (1975) Cell shape and membrane changes in the eight-cell mouse embryo: prerequisite for morphogenesis of the blastocyst. Devl Biol. 47, 45-58.

Ducibella, T., Albertini, D.F., Anderson, E. \& Biggers, J.D. (1975) The preimplantation mammalian embryo: characterization of intercellular junctions and their appearance during development. Devl Biol. 445, $231-250$.

Edelman, I.S., Pressley, T.A. \& Hiatt, A. (1985) Regulation of mammalian Na,K-ATPase. In The Sodium Pump, pp. 153-159. Eds I. Glynn \& C. Ellory. Company of Biologists Limited, Cambridge.

Epstein, C.J. \& Smith, A.S. (1973) Amino acid uptake and protein synthesis in preimplantation mouse embryos. Devl Biol. 33, 171-184.

Fisher, R.A. (1920) Studies in crop variation. I. An examination of the yield of dressed grain from Broadbalk. J. agric. Sci., Cambr. 11, 107-135.

Gamow, E. \& Daniel, J.C., Jr (1970) Fluid transport in the rabbit blastocyst. Wilhelm Roux Arch. Entn Mech. 164, 261-278.

Geheb, M., Alvis, R., Hercker, E. \& Cox, M. (1983) Mineralocorticoid-specificity of aldosterone-induced protein synthesis in giant-toad (Bufo marinus) urinary bladders. Biochem. J. 214, 29-35.

Hastings, R.A. \& Enders, A.C. (1975) Junctional complexes in the preimplantation rabbit embryo. Anat. Rec. 181, 17-34.
Hines, W.G.S. (1983) Geometric mean. In Encyclopedia of Statistical Sciences, Vol. 3, pp. 397-400. Eds S. Kotz \& N. L. Johnson. Wiley, New York.

Jaszezak, S., Hafez, E.S.E., Moghissi, K.S. \& Kurrie, D.A. (1972) Concentration gradients of amino acids between the uterine and blastocoelic fluid in the rabbit. Fert. Steril. 23, 405-409.

Jorgenssen, P.L. (1972) The role of aldosterone in the regulation of $\mathrm{Na}^{+} / \mathrm{K}^{+}$ATPase in rat kidney. $J$. Steroid Biochem. 3, 181-191.

Jorgenssen, P.L. (1974) Purification and characterization of $\mathrm{Na}^{+} / \mathrm{K}^{+}$ATPase. III. Purification from the outer renal medulla of mammalian kidney after selective removal of membrane components by sodium dodecylsulphate. Biochim. Biophys. Acta 356, 36-52.

Lesinski, J., Jajszczak, S., Bentyn, K. \& Janczarski, I. (1967) Concentration of free amino acids in rabbit blastocyst fluid. Am. J. Obstet. Gynecol. 99, 280-283.

Lo, C.S. \& Edelman, I.S. (1976) Effect of triiodothyronine on the synthesis and degradation of renal cortical $\left(\mathrm{Na}^{+}+\mathrm{K}^{+}\right)$-adenosine triphosphatase. J. biol. Chem. 251, 7834-7840.

MeDonough, A.A., Brown, T.A., Horowitz, B., Chiu, R., Schlotterbeck, J., Bowen, J. \& Schmitt, C.A. (1988) Thyroid hormone coordinately regulates $\mathrm{Na}^{+}-\mathrm{K}^{+}$ATPase-and -subunit mRNA levels in kidney. $\mathrm{Am}$. J. Physiol. 254 (Cell Physiol. 23), C323-C329.

Miller, J.G.O. \& Schultz, G.A. (1987) Amino acid content of preimplantation rabbit embryos and fluids of the reproductive tract. Biol. Reprod. 36, 126-129.

Morrissey, J.H. (1981) Silver stain for proteins in polyacrylamide gels: modified procedure with enhanced uniform sensitivity. Analyt. Biochem. 117, 307-310.

O'Farrell, P.H. (1975) High resolution two-dimensional electrophoresis of proteins. J. biol. Chem. 250, 4007-4021.

Overstrom, E.W., Benos, D.J. \& Biggers, J.D. (1983) Radio-iodination of apical and basal-lateral plasma membranes of preimplantation rabbit blastocysts. Biol. Reprod. 28 (Suppl. 1), I4l, Abstr.

Paccolat, M.P., Geering, K., Gaeggeler, H.P. \& Rossier, B.C. (1987) Aldosterone regulation of $\mathrm{Na}^{+}$transport and $\mathrm{Na}^{+} \cdot \mathrm{K}^{+}$-ATPase in A6 cells: role of growth conditions. Am. J. Physiol. 252 (Cell Physiol. 21), C468 C476.

Petzoldt, U., Briel, G., Gottschewski, G.H.M. \& Neuhoff, V. (1973) Free amino acids in the early cleavage stages of the rabbit egg. Devl Biol. 31, 38-46.

Pollack, L.R., Tate, E.H. \& Cook, J.S. (1981) Turnover and regulation of $\mathrm{Na}^{+} / \mathrm{K}^{+}$ATPase in HeLa cells. $\mathrm{Am}$. J. Physiol. 241, C173-C183.

Regier, J.C. \& Kafatos, F.C. (1971) Microtechnique for determining the specific activity of radioactive intracellular leucine and applications to in vivo studies of protein synthesis. J. biol. Chem. 246, 6480-6488.

Schultz, R.M., Letourneau, G.E. \& Wasserman, P.M. (1979) Program of early development in the mammal: changes in patterns and absolute rates of tubulin and total protein synthesis during oogenesis and early embryogenesis in the mouse. Devl Biol. 68, $341-359$

Skou, J.C. \& Esmann, M. (1979) Preparation of membrane-bound and of solubilized $\left(\mathrm{Na}^{+} / \mathrm{K}^{+}\right)$-ATPase from rectal glands of Squalus acanthias. Biochim. Biophys. Acta 567, 436-444. 
Smith, M.W. (1970) Active transport in the rabbit blastocyst. Experientia 26, 736-738.

Sokal, R.R. \& Rohlf, F.J. (1981) Biometry, 2nd edn. Freeman and $\mathrm{Co}$., San Francisco.

Tarone, G., Ferracini, R., Galetto, C. \& Comoglio, P. (1984) A cell surface integral membrane glycoprotein of $85000 \mathrm{molwt}$ (gp 85) associated with Triton X-100-insoluble cell cytoskeleton. J. Cell Biol. 99, 512-519.

Van Blerkom, J. (1978) Methods for the high resolution analysis of protein synthesis: applications to studies of early mammalian development. In Methods in Mammalian Reproduction, pp. 67-109. Ed. J. C. Daniel, Jr. Academic Press, New York.

Van Blerkom, J. \& Manes, C. (1974) Development of preimplantation rabbit embryos. II. A comparison of qualitative aspects of protein synthesis. Devl Biol. 40, 40-51.

Watson, A.J. \& Kidder, G.M. (1988) Immunofluorescence assessment of the timing of appearance and the cellular distribution of $\mathrm{Na} / \mathrm{K}$-ATPase during mouse embryogenesis. Devl Biol. 126, 80-90.

Wiley, L.M. (1984) Cavitation in the mouse preimplantation embryo: $\mathrm{Na} / \mathrm{K}-\mathrm{ATPase}$ and the origin of nascent blastocoele fluid. Devl Biol. 105, 330-342.

Ziomek, C. \& Johnson, M.H. (1980) Cell surface interaction induces polarization of mouse eight-cell blastomeres at compaction. Cell 21, 935-942.

Received 20 June 1988 